\title{
Chemical Castration of Rabbits Via Intratesticular Injection of Ethanol or Formalin
}

\author{
A A Majeed \\ Department of Surgery and Obstetrics, College of Veterinary Medicine, Baghdad University, Iraq.
}

\section{Accepted on Jan- 2011}

\section{Summary}

The purpose of the study was to determine the efficacy and safety of intratesticular injection of ethanol or formalin as a novel method for chemosterilization of rabbits. Twenty rabbits, aged (6-8 months) and weighed (1.3-1.5) $\mathrm{kg}$ were used. They were randomly divided into two equal groups. In the first group, absolute ethanol and in the second group, formalin $1 \%$ at a dose of $1 \mathrm{ml} /$ testis for each agent were injected under the effect of xylazine, by insertion of the needle from the caudo-ventral aspect of the testis then pushed in the center of the testis toward the cranio-dorsal pole of the testis. Orchidectomy was done at first and second months postinjection, samples from the testes and epididymis were taken for histopathological evaluation of testicular changes. Histopathological examination revealed atrophy of the seminiferous tubules, degeneration or vacuolation of sertoli cells and the leydig cells replaced by fibrous connective tissue. The of epididymis show narrowing of the epididymal lumen. The severity and distribution of the lesions were more pronounced in formalin group, although both agents had the ability to induce sterilization in rabbits.

\section{الاخصاء الكيميائي في الأرانب بحقن الكحول اوالفورمالين داخل الخصية

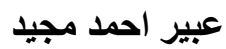 \\ فرع الجراحة والتوليد، كلية الطب البيطري، جامعة بغداد، العراق}

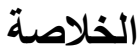

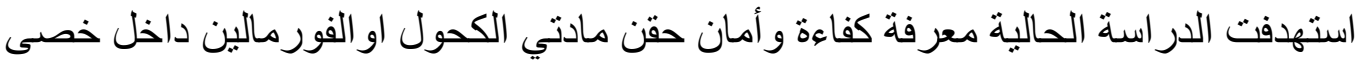

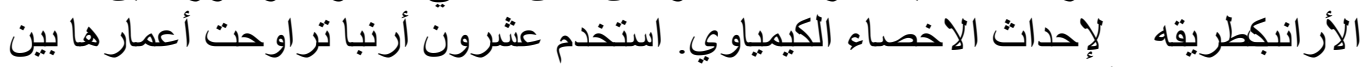

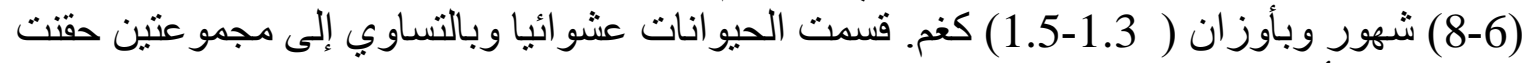

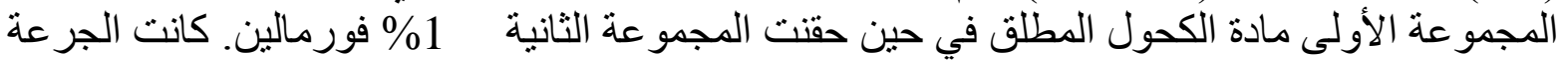

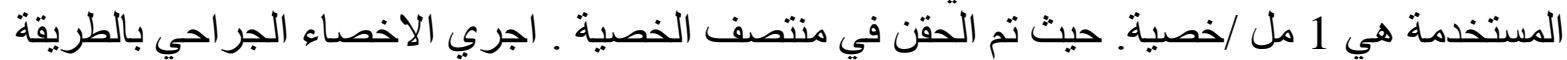

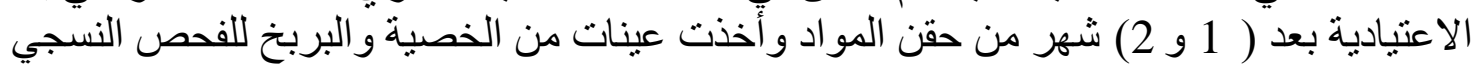

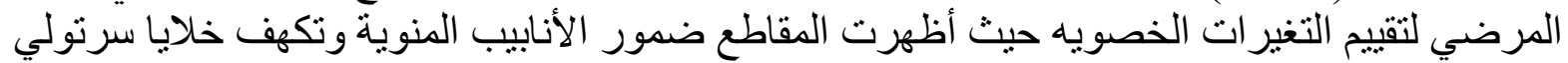

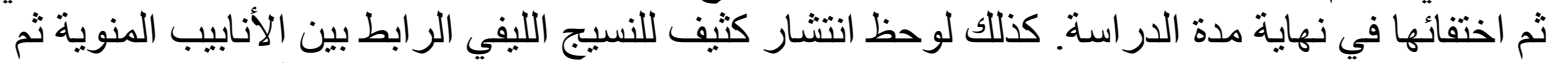

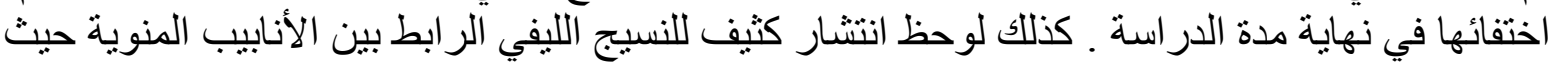

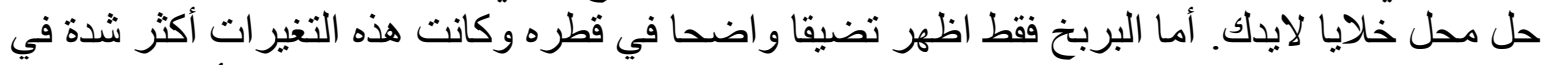
المجمو عة المعاملة بالفورمالين. وإن كلتا المادتين استطاعت إيقاف وظيفة الخصية في الأر انب. 


\section{Introduction}

Castration means removal of the testes and associated structures such as epididymis and part of the spermatic cord (1). Castration of male rabbit is recommended in order to reduce difficult behavior, like marking of its territory with strong smelling urine, aggressive attitudes and prevents mating in multirabbit household (2). Furthermore there are medical reasons to favor the castration such as chronic orchitis or epididymitis and testicular neoplasms (3). There are two primary methods used to castrate a rabbit (closed and open). The secondary health problems are not uncommon following castration especially the open type such as hemorrhage, herniation and even death (4 and 5).To avoid such complications, a non-surgical technique for rabbit castration was performed in this study represented by intratesticular injection of ethanol or formalin to evaluate the efficacy and safety of these agents in inducing sterilization in rabbits, documented by histopathological examinations of the testes and epididymis.

\section{Materials and Methods}

Twenty apparently healthy rabbits aged from (6-8) months and weighed (1.3-1.5) $\mathrm{kg}$ were used. Rabbits were randomly allotted into two equal groups each group allotted into two equal subgroup depended on follow up at 30 and 60 days post operation. All rabbits were clinically examined and confirmed to be free from any obvious abnormalities of the palpable reproductive organs.

Intratesticula injection was done under the effect of the xylazine hydrochloride $2 \%$ in a dose of $10 \mathrm{mg} / \mathrm{kg} \mathrm{B.W}$ intramuscularly. The scrotum was prepared aseptically. A sterile needle gauge 21 was inserted from the caudoventral aspect of the testis then pushed in the center of the testis toward the cranio-dorsal pole of the testis (fig.1). In the first group, absolute ethanol while in the second group $1 \%$ formalin were injected, at a dose of $1 \mathrm{ml}$.

Bilateral orchidectomy (Fig. 2-5) according to the technique used by (6) were done 30 and 60 days post injection. Ten rabbits used for each group (five rabbits/period). Orchidectomy was performed under the effect of general anesthesia represented by IM injection of ketamine-xylazine combination in a dose of $40 \mathrm{mg} / \mathrm{kg}$ and $20 \mathrm{mg} / \mathrm{kg} \mathrm{B.W}$. respectively. Testicular biopsies were harvested and fixed in $10 \%$ neutral buffered formaline and passed routinely to prepare histopathological sections and were stained with Hematoxyline-Eosine stain and examined under light microscope (7). 


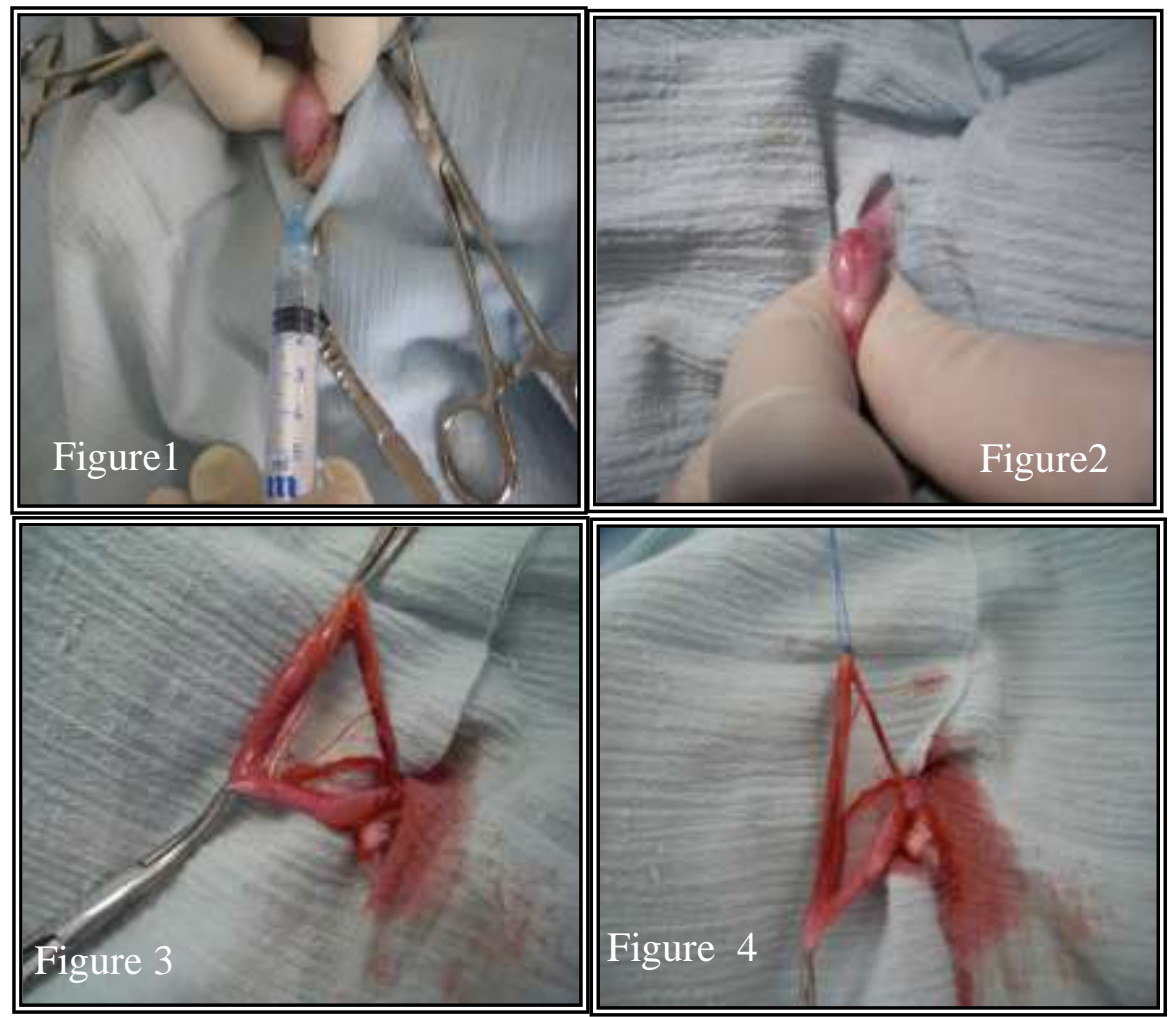

Figure1: Technique of intratesticular injection

Figure 2: The scrotum is incised and the testis is exteriorized

Figure 3: The testis and epididymis are exposed through scrotal incision.

Figure 4: The spermatic cord is ligated by silk.

\section{Results}

Clinical Observations: The time required for intratesticular injection of both agents was relatively short, it ranged from (22-30) second/testis. As with any medication there were possible side effects evocated from injection such as swelling and hardening of the testes of all rabbits which reached its peak during the first 48 hours following injection, then subsided gradually and the testes retained to their normal consistency in 5-7 days post injection. Some rabbits reflected a short painful period but this did not affects food consumption. Other reactions included biting or licking the site of injection. These signs were more pronounced in second group. Three rabbits, two from the formalin group and one from the ethanol group, showed scrotal ulcer. All mentioned complications were minor, transient and subsided without any treatment. With one exception (rabbit with scrotal ulcer related to formalin group which nessciated surgical removal of the affected testes.

Histopathological findings: Ethanol Group: Microscopical picture of the testis at one month in ethanol group, showed irregular shape of the seminiferous tubules which surrounded by inflammatory zone consist mainly of the mononuclear cells. The spermatogonia reflected vacuolar degeneration (Fig.5). At two months post injection of ethanol, testis revealed degenerative seminal products in the lumen of seminiferous tubules, in addition proliferation of fibrous connective tissue (Fig.6). Epididymal section reflected narrowing of epididymal lumen due to proliferation of fibrous connectives tissue (Fig. 7). 
While in formalin group: One month post injection testis showed hyalinization of the seminiferous tubules surrounded by interstitial fibrosis (Fig. 8). Two months following injection, the seminiferous tubules devoid of spermatogonia and sertoli cells, also presence of interstitial fibrosis which replaced the leydig cells (Fig.9). Section obtained from the epididymis reflected similar picture seen in ethanol group (Fig.10).

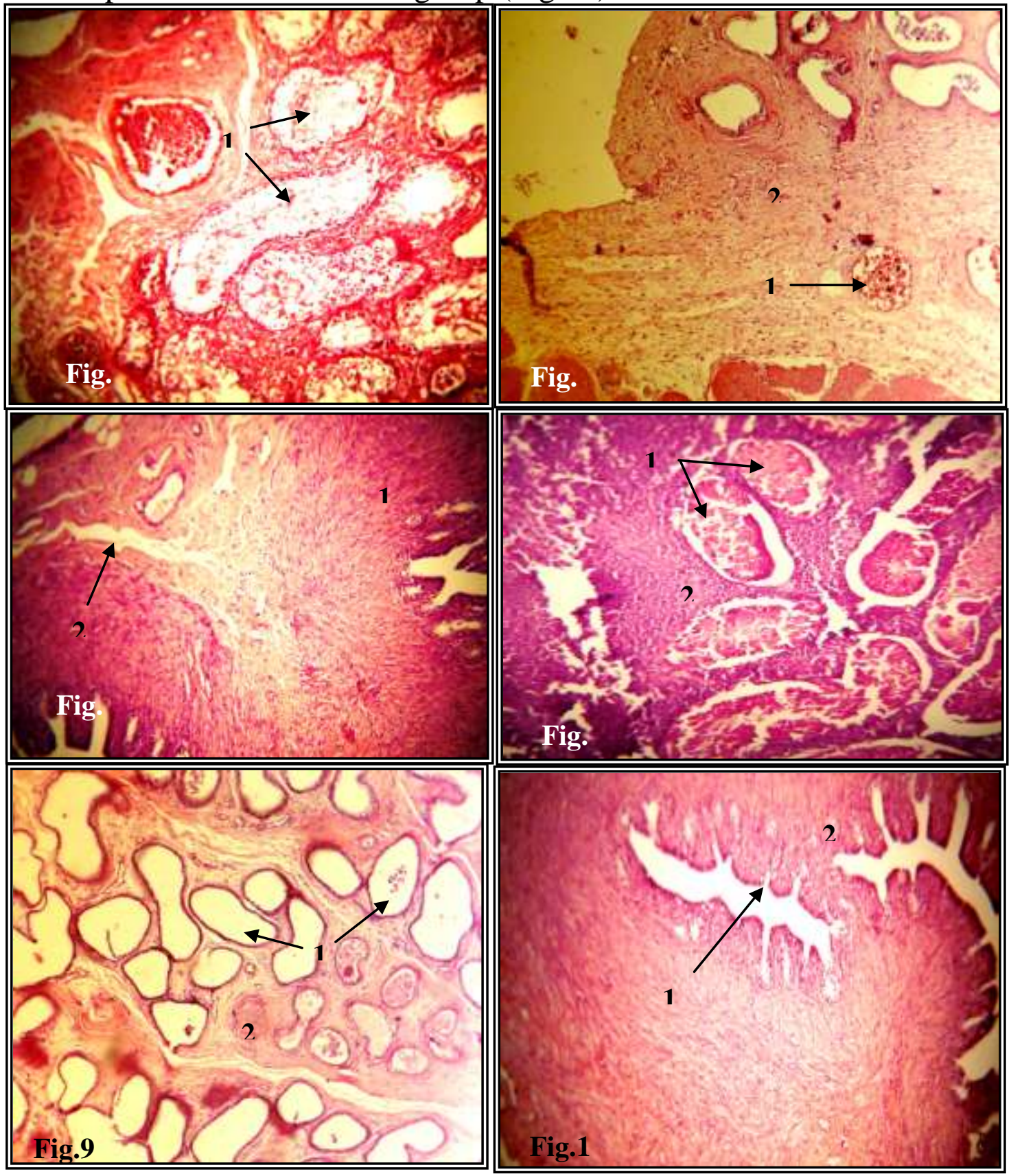

Figure 5: Histopathological section of testis, one month post injection of ethanol shows irregular shape of seminiferous tubules (1) surrounded by inflammatory zone (2) and vacuolar degeneration of spermatogonia (3) (H\&E X10). Figure 6: Histopathological section of testis, two months post injection of ethanol shows atrophy of seminiferous tubule which containing degenerative seminal products in their lumen (1) also fibrous connective tissue surrounding the tubules (2) (H\&E X10). Figure 7: Histopathological section of epididymis, two months post injection of ethanol shows fibrosis (1) and construction of the epididymal lumen (2) (H\&E X10). Figure 8: Histopathological section of testis, one month post injection of formalin shows hyalinized seminiferous tubules (1) surrounded by fibrosis (2) (H\&E X10). Figure 9: Histopathological section of testis, two months post injection of formalin shows seminiferous tubules devoid of spermatogonia and sertoli cells (1) also obscene of leydig cells in the interstitial tissue (2) (H\&E X10). Figure 10: Histopathological section of epididymis, two months post injection of formalin shows severe diffuse interstitial fibrosis (1) with narrowing of ductus epididymis (2)(H\&E X10). 


\section{Discussion}

Chemosterilization of the rabbits in the present study required a shorter time to be performed when compared with surgical castration because the latter requires general anesthesia, opening of the scrotum and ligation of the spermatic cord and a period of healing and thus are relatively complicated (3). Many surgeons $(8,9$ and 10), indicated that surgical castration can be done within a time not less than $(10 \pm 2.0)$ minutes/testis. This means that the time for intratesticular injection is approximately (20) times shorter than the surgical type and this is important when castrating a herd of animals. Directly following the injection of ethanol or formalin, the testes become swollen and tender which it is an expected reaction to injection. These finding also reported by (2 and 11). Biting or licking the site of injection may be due to irritation caused by the injectable agents used in this study. This agree with a study performed in guinea pig (12). Scrotal ulceration were noticed in three rabbits and this may be attributed to the technical error (movement of animal during injection) resulting in distribution of the chemical agent in non-target tissue (scrotum). Thus good restraining and sedation are important during intratesticular injection to avoid such complications. In a study by (11), glycerol injected intratesticularly in four dogs, resulted in ulceration due to licking the site of injection and self induced trauma. Scrotal ulcer also recorded in monkeys over 10 weeks age (13).

The histopathological findings following intratesticular injection of ethanol or formalin solution exhibit that impairment of spermatogenesis in rabbit due to breakage of the sertoli cells and localized inflammation. In addition the fibrosis of interstitial space which replaced the leydig cells indicate that these cells are incapable to produce testosterone. These findings were noticed in previous studies (14, 15 and 16), whom using various chemical agents in different species.

The technique used in this study had several desirable characteristics such as simplicity, inexpensive, not needed for experience, free from serious complications.

\section{References}

1. Millis D L and Walshaw R S (1992). Elective castration of pet rabbits. J. Am. Anim. Hosp. Assoc., 108(3):491-497.

2. Jenkins J R (2000). Surgical sterilization in small mammals. Spay and castration. Vet. Clin. North Am. Exot. Anim. Pract 3(3):817-827.

3. Kamyar T T Sakineh A and Elena S (2008). Pattern of compensatory hypertrophy in contralateral testis after unilateral orchidectomy in immature rabbits. Urol J 6(3): 199203.

4. Hussein S A Azab M E and Abdel-Maksoud H (1999). Metabolic changes concerning the effect of castration on some blood constituents in male rabbit. Dtsch Tierazti Wochenschr. 106(3):113-118.

5. Quesenberry K E Carepenter J W and Quesenberry P (2004). Rabbits and Rodents: Clinical Medicine and Surgery. Elsevier Health.2ed, Pp: 416-421.

6. Praag, E. (2007). Male reproductive tract and orchidectomy (castration surgery). Urogenital Tract of Rabbits Urology-15(5):37-43. 
7. Sanefuji T (1988). Tissue culture studies of the young rabbit after hemicastration. Hinyokika Kiyo Japanese.34:585-591.

8. Nishimura N Kawate N Sawada T and Mori J (1992). Chemical castration by single intratesticular injection of lactic acid in rats and dogs. J. Reprod. Dev. 38:263-266.

9. Bloomberg M S (1996). Surgical; neutering and non-surgical alternative. J. Am Vet Med Assoc. 208:517-519.

10. Stafford K (2007). Castration of older lambs referring to their complications. Vet. J. 179:477481.

11. Immegart H I and Threlfall W R (2001). Evaluation of intratesticular injection of glycerol for nonsurgical sterilization of dogs. Am J Vet Res. 61:544-549.

12. Giri S C Yadav B P and Panda S K (2002). Chemical castration of guinea pigs. Indian J of Anim Sci. 72:451-453.

13. Kar A B Kamboj V P and Goswami A (1995). Sterilization of male rhesus monkeys by iron salts. J Reprod and Fertil. 9:115-117.

14. Weinbauer G F Galhotra M M and Nieschlage E (1985). Focal testicular destruction following intratesticular injection of glycerol in rats. Int J Androl. 8:365-375.

15. Russel L D Ettlin R P and Sinhahikin A P (1990). Histological and histopathological evaluation of the testis. Clearwater CacheRiver Press 3ed.Pp:127_132

16. Monbeini H Mosapour S and Aghaee A (2001). The evaluation of hormonal and histologic changes in contralateral testis after unilateral orchidectomy in white rabbit. Iran J Urol. 29:29-33. 